\title{
Effects of Ammonium Nitrogen on Lettuce Grown on Pumice in a Closed Hydroponic System
}

\author{
D. Savvas', H.C. Passam, and C. Olympios \\ Agricultural University of Athens, Laboratory of Vegetable Production, Iera \\ Odos 75, 11855 Athens, Greece
}

\author{
E. Nasi, E. Moustaka, N. Mantzos, and P. Barouchas \\ Faculty of Agricultural Technology, T.E.I. of Epirus, P.O. Box 110, 47100 \\ Arta, Greece
}

Additional index words. nitrogen form, Lactuca sativa, soilless culture, recycling

\begin{abstract}
Two successive lettuce crops were grown in spring 2005 in a completely closed hydroponic system. The ratio of ammonium to total nitrogen $\left(N_{r}\right)$ in the fresh nutrient solution (FNS) introduced into the closed system to compensate for plant uptake was 0 , $0.1,0.2$ and 0.3 on a molar basis. In all $N_{r}$ treatments, the concentrations of total $\mathrm{N}, \mathrm{K}, \mathrm{Ca}$, $\mathrm{Mg}, \mathrm{P}$, and micronutrients in the FNS were identical, but that of $\mathrm{SO}_{4}{ }^{2-}$ increased as $N_{r}$ increased, to compensate electrochemically for the enhanced $\mathrm{NH}_{4}{ }^{+}$and decreased $\mathrm{NO}_{3}{ }^{-}$ supply. The highest fresh and dry weights per plant were attained with the highest ammonium supply $\left(N_{r}=0.3\right)$ but, even when no $\mathrm{NH}_{4}^{+}$was included in the FNS as an N source, the plants were healthy without apparent nutritional disorders. The ammonium concentration in the drainage solution dropped to nearly zero in all treatments some days after the initiation of recycling, which implies a preferential uptake of $\mathrm{NH}_{4}-\mathrm{N}$ over $\mathrm{NO}_{3}-\mathrm{N}$. The root zone $\mathrm{pH}$, as indicated by the values measured in the drainage solution, decreased slightly as $N_{r}$ increased, and ranged from 6.5 to 8.0 in all treatments. The leaf $\mathrm{K}, \mathrm{Ca}, \mathrm{Mg}$, and Fe concentrations were not influenced, whereas those of $\mathrm{P}, \mathrm{Mn}, \mathrm{Zn}$, and $\mathrm{Cu}$ were enhanced by the increasing $\mathrm{NH}_{4}^{+}$supply. The increased ammonium supply did not enhance the utilization of $\mathrm{N}$ in plant metabolism, although it reduced the nitrate concentration of the internal leaves in the early spring experiment. The leaf micronutrient concentrations were clearly more than critical levels even when $\mathrm{NO}_{3}{ }^{-}$was the sole $\mathbf{N}$ source for lettuce, whereas the $\mathbf{P}$ concentration approached the lowest critical level when $N_{r}$ was 0 or 0.1 . The stimulation of lettuce growth as $N_{r}$ was increased to 0.3 may be a consequence of enhanced $\mathrm{P}$ uptake resulting from better control of $\mathrm{pH}$ in the root zone.
\end{abstract}

Nitrogen is the only nutrient that can be supplied to plants via fertigation in both anionic $\left(\mathrm{NO}_{3}^{-}\right)$and cationic $\left(\mathrm{NH}_{4}^{+}\right)$form, whereas the uptake rates of both $\mathrm{N}$ forms are influenced by their external concentrations (Forde and Clarkson, 1999). However, the manipulation of $\mathrm{NH}_{4}-\mathrm{N} / \mathrm{NO}_{3}-\mathrm{N}$ in the nutrient solution supplied to the plants, while maintaining the same total-N concentration, may considerably modify the total cation-toanion uptake ratio. Changes in the total cation-to-anion uptake ratio have a profound impact on the $\mathrm{pH}$ in the root zone (Imas et al., 1997; Lea-Cox et al., 1996). Indeed, the imbalance of total cation over anion uptake in the rhizosphere originating from enhanced $\mathrm{NH}_{4}{ }^{+}$uptake is electrochemically compensated for by the release of protons $\left(\mathrm{H}^{+}\right)$, which results in a lowering of the medium $\mathrm{pH}$

Received for publication 26 Apr. 2006. Accepted for publication 14 July 2006.

This investigation was supported by the Greek Ministry of Education (YPEPTH) within the frame of the "ARCHIMEDES" research project, which was partly funded by EU. We thank LAVA S.A. for donating the substrate (pumice).

${ }^{1}$ To whom reprint requests should be addressed; e-maildsavvas@aua.gr.
(Bolan et al., 1991; Imas et al., 1997). Similarly, the excess of anion over cation uptake by the plants resulting from the supply of $\mathrm{NO}_{3}^{-}$as the sole or dominant $\mathrm{N}$ form is compensated for by $\mathrm{H}^{+}$influx or equivalent anion extrusion (Barber, 1984; Imas et al., 1997; Magalhaes and Wilcox, 1983), which increases the $\mathrm{pH}$ of the external solution. The $\mathrm{pH}$ of the external medium may influence the uptake of $\mathrm{P}$ and micronutrients, thereby inducing serious nutritional disturbances (Adams, 2002; Imas et al., 1997; Islam et al., 1980; Savvas et al., 2003). Furthermore, the form of $\mathrm{N}$ supplied may influence the uptake of other macronutrients resulting from ion antagonism (Marschner, 1995). The $\mathrm{N}$ form also influences plant metabolism, resulting from differences in the intracellular assimilation paths (Gerendás et al., 1997; Raab and Terry, 1994) and the accumulation of nitrate (Blom-Zandstra, 1989).

As a rule, the use of ammonium as the sole or principal $\mathrm{N}$ source results in impaired growth and yield reductions (Chaillou et al., 1986; Chance et al., 1999; Claussen and Lenz, 1999; Guo et al., 2002; Raab and Terry, 1994). This is ascribed to the high toxicity of ammonia at an intracellular level (Barker and Mills, 1980; Givan, 1979; Raab and Terry,
1994). The current recommendation for soilless culture is that $\mathrm{NH}_{4}-\mathrm{N}$ should not exceed $25 \%$ of the total-N supply (Sonneveld, 2002). However, plant species differ in their response to the $\mathrm{NH}_{4}-\mathrm{N} /$ total- $\mathrm{N}$ supply ratio and root zone pH (Akl et al., 2003; Beevers and Hageman, 1983; Claussen and Lenz, 1999; Islam et al., 1980). The changes in nutrient concentrations and $\mathrm{pH}$ in the root zone of soilless-grown plants may be rapid as a result of the restricted volume of the rooting medium and a lack of buffering capacity. Moreover, the impact of a particular $\mathrm{NH}_{4}-\mathrm{N}$ / total-N supply ratio may be quite different in closed hydroponic systems than in open ones (Savvas and Gizas, 2002). Hence, to prevent nutrient disturbances and to optimize growth in crops grown in closed hydroponic systems, specific knowledge is required for each particular plant species concerning its response to the ratio of $\mathrm{NH}_{4}-\mathrm{N}$ to total- $\mathrm{N}$ supply via the nutrient solution.

High $\mathrm{NO}_{3}{ }^{-}$concentrations in edible plant parts constitute a potential threat for human health and, therefore, many countries have set maximum permissible values by legislation (Blom Zandstra, 1989; Van der Boon et al., 1990). Many plants tend to accumulate nitrate in their leaves, and lettuce is one of these (Gent, 2003). To restrict the accumulation of $\mathrm{NO}_{3}{ }^{-}$in lettuce, a partial substitution of $\mathrm{NH}_{4}{ }^{+}$for $\mathrm{NO}_{3}{ }^{-}$has been tested in crops grown in recirculating nutrient solution (Ikeda and Osawa, 1981; Van der Boon et al., 1990) and in pots filled with an organic substrate (Scaife et al., 1986). The previously mentioned investigations focused mainly on plant growth and tissue nitrate levels. The current study was designed to investigate the responses of lettuce to $\mathrm{NH}_{4}-\mathrm{N} /$ total-N when the plants are grown on an inert substrate (pumice) under Mediterranean climatic conditions and the drainage solution is completely recycled. To understand better the mechanisms underlying the effects of $\mathrm{NH}_{4}^{+}$ and $\mathrm{NO}_{3}{ }^{-}$on lettuce growth, our study focuses not only on plant growth and tissue nitrate concentrations, but also on the nutrient status in the root zone and the uptake of nutrients.

\section{Materials and Methods}

Two successive experiments with lettuce (Lactuca sativa L., cv. Vardac) were carried out in a glasshouse located in Arta (lat. $39^{\circ} 7^{\prime} \mathrm{N}$, long. $20^{\circ} 56^{\prime} \mathrm{E}$ ), Greece. The experiments were conducted in 12 independent hydroponic installations enabling complete recycling of the drainage solution, which corresponded to 12 experimental units. Each experimental unit comprised two channels, $5 \mathrm{~m}$ in length and $0.25 \mathrm{~m}$ in width. The channels were filled with pumice (particle size range, $0-5 \mathrm{~mm}$ ) to a depth of $8 \mathrm{~cm}$. Each channel accommodated 40 plants and, hence, the volume of substrate per plant was $2.5 \mathrm{~L}$. All channels were covered with black-white polyethylene sheets to avoid water evaporation. Nutrient solution was automatically applied via a drip irrigation system at a rate 
of $0.12 \mathrm{~L}$ per plant per irrigation event, at intervals depending on solar radiation intensity, which was monitored using a pyranometer. The solar integral at which an irrigation event was triggered was regularly adjusted to values maintaining the drainage percentage within a range of $35 \%$ to $50 \%$. This schedule resulted in three to eight irrigation applications per day to each experimental unit, depending on the prevailing weather conditions. The nutrient solution supplied to the crop, henceforth termed irrigation solution, was prepared by blending the entire amount of drainage solution occurring after each irrigation event with fresh nutrient solution (FNS) and adjusting the $\mathrm{pH}$ to 5.6 using nitric acid. A fully automated installation was used to blend FNS with drainage solution up to a constant preset volume, adjust $\mathrm{pH}$, and supply the resultant irrigation solution to the crop. This process was performed separately for each of the 12 experimental units in a successive sequence.

Four different treatments of FNS were obtained by injecting nitrogen at four $\mathrm{NH}_{4}-\mathrm{N}$ to-total- $\mathrm{N}$ ratios $\left(N_{r}\right)$ corresponding to 0.0 , $0.1,0.2$, and 0.3 on a molar basis. The total-N concentration was $11.7 \mathrm{~mm}$ in the FNS of all four treatments, which were arranged in a randomized complete block design with three blocks. The nutrient concentrations in all treatments of FNS were as follows: 9.2 $\mathrm{mm} \mathrm{K}, 2.0 \mathrm{~mm} \mathrm{Ca}, 1.0 \mathrm{~mm} \mathrm{Mg}, 1.3 \mathrm{~mm} \mathrm{P}, 40$ $\mu \mathrm{M} \mathrm{Fe}, 5 \mu \mathrm{M}$ Mn, $4 \mu \mathrm{M} \mathrm{Zn}, 0.75 \mu \mathrm{M} \mathrm{Cu}, 30 \mu \mathrm{M}$ $\mathrm{B}$, and $0.5 \mu \mathrm{M}$ Mo. To attain identical $\mathrm{K}, \mathrm{Ca}$, $\mathrm{Mg}$, total- $\mathrm{N}$, and $\mathrm{P}$ concentrations in all treatments, the changes in the $\mathrm{NH}_{4}-\mathrm{N}$-tototal- $\mathrm{N}$ ratio were balanced by varying the sulfate concentration from 0.8 to $4.2 \mathrm{~mm}$ and the electrical conductivity of the FNS (EC) from 1.78 to $2.14 \mathrm{dS} \cdot \mathrm{m}^{-1}$. The mean EC values in the drainage solution ranged from 1.84 to $2.32 \mathrm{dS} \cdot \mathrm{m}^{-1}$ and from 1.92 to 2.44 $\mathrm{dS} \cdot \mathrm{m}^{-1}$ in the early and late spring experiments, respectively. According to Shannon and Grieve (1999), differences in EC within this range in the root zone are not expected to influence the growth of lettuce significantly, and hence any significant differences should be ascribed to the $N_{r}$ treatments.

In the first experiment, planting took place on $21 \mathrm{Feb}$. at the stage of three true leaves and harvesting on 5 Apr. 2005, whereas in the second experiment (which repeated the first) the plants were planted on 21 Apr. and harvested on 25 May 2005. In the early spring experiment, the inside air temperature ranged from 14 to $18{ }^{\circ} \mathrm{C}$ during the night and from 15 to $27{ }^{\circ} \mathrm{C}$ during the day, whereas the maximum and minimum daily solar radiation inside the greenhouse was $156 \mathrm{Wh} \cdot \mathrm{m}^{2}$ and $3398 \mathrm{Wh} \cdot \mathrm{m}^{2}$ (average, $1707 \mathrm{Wh} \cdot \mathrm{m}^{2}$ ). In the late spring experiment, the air temperature inside the greenhouse fluctuated from 16 to $22{ }^{\circ} \mathrm{C}$ (night) and from 17 to $29{ }^{\circ} \mathrm{C}$ (day), whereas the maximum and minimum daily solar radiation was $743 \mathrm{Wh} \cdot \mathrm{m}^{2}$ and 3788 $\mathrm{Wh} \cdot \mathrm{m}^{2}$ (average, $2425 \mathrm{Wh} \cdot \mathrm{m}^{2}$ ). The mean root temperature was $16.5^{\circ} \mathrm{C}$ and $20.7^{\circ} \mathrm{C}$ in the early and the late spring experiments respectively. In both experiments, the plants were harvested at the stage of commercial maturity (complete head formation) following the common growing practice for the particular cultivar.

Immediately after planting, the plants of each treatment were supplied with the FNS corresponding to each treatment. Recycling of the drainage solution was initiated $3 \mathrm{~d}$ after planting by automatically mixing FNS with drainage solution as described earlier, and this process was continued until the end of the experiment. The $\mathrm{pH}$ of the drainage solution, which was considered to be an indicator for the $\mathrm{pH}$ status in the root environment, was measured and recorded automatically in an Access $^{\circledR}$ database whenever irrigation solution was prepared. At regular time intervals, three samples of drainage solution were selected from each treatment and used to determine the $\mathrm{NH}_{4}{ }^{+}$concentration at $640 \mathrm{~nm}$ by the phenate method and the $\mathrm{NO}_{3}{ }^{-}$concentration at $540 \mathrm{~nm}$ after reduction to nitrite by cadmium and formation of a diazo complex (Eaton et al., 1995). To monitor the nutrient status in the root zone, the concentrations of all metallic nutrients $(\mathrm{K}, \mathrm{Ca}, \mathrm{Mg}, \mathrm{Mn}, \mathrm{Zn}, \mathrm{Fe}$, $\mathrm{Cu})$ and $\mathrm{P}$ in the drainage solution were also measured at two sampling dates. $\mathrm{P}$ was determined colorimetrically as phosphomolybdate blue complex at $880 \mathrm{~nm}$. The metallic cations were measured by atomic emission spectrophotometry (Perkin Elmer, AAnalyst 100), whereas $\mathrm{NH}_{4}{ }^{+}, \mathrm{P}$, and $\mathrm{NO}_{3}{ }^{-}$were determined using a continuous flow analyzer, type $\mathrm{San}^{++}$of SKALAR (Breda, The Netherlands).

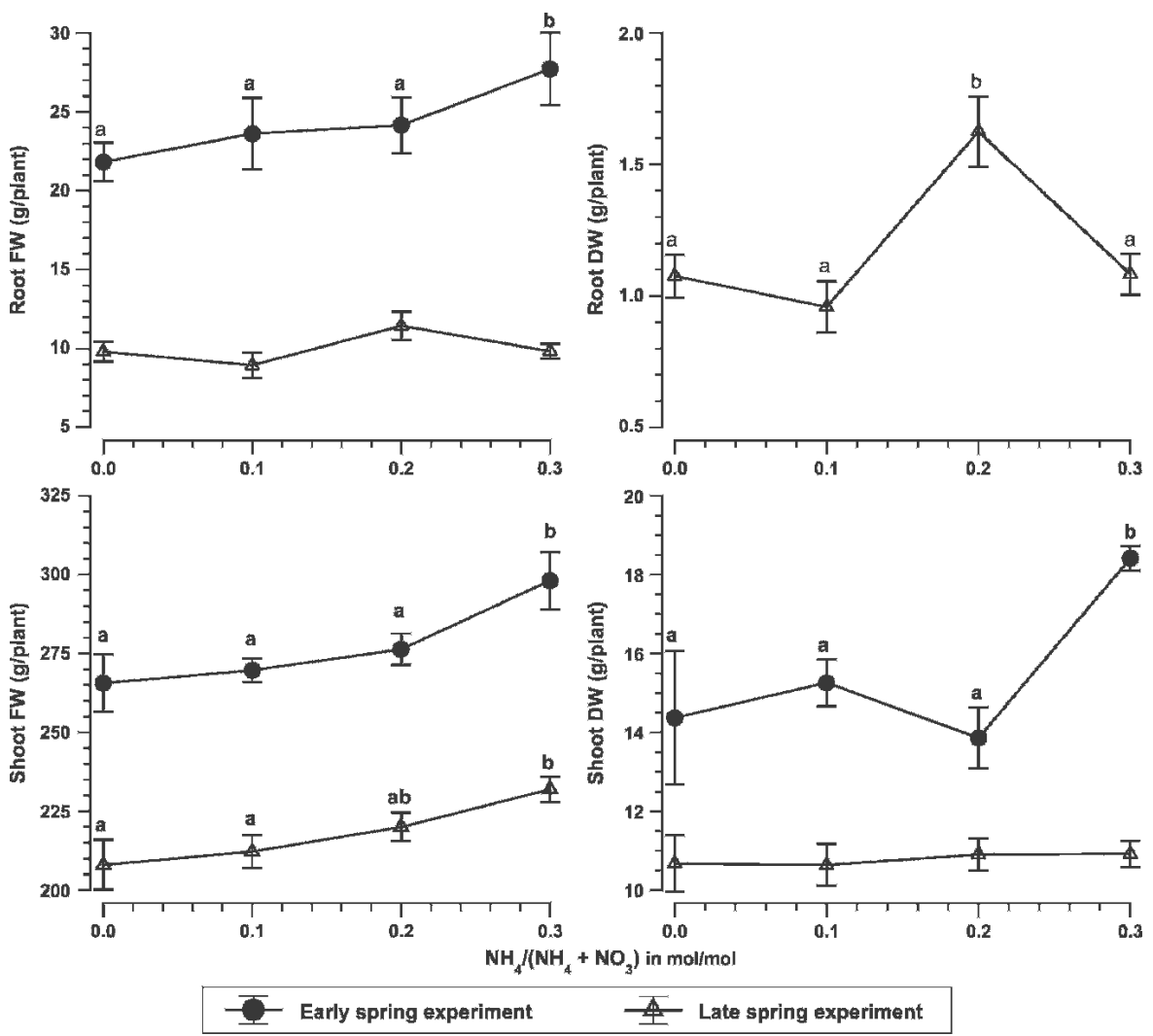

Fig. 1. Fresh and dry weight of lettuce as influenced by $\mathrm{NH}_{4} /$ total-N $\left(N_{r}\right)$ in the fresh nutrient solution introduced into a closed hydroponic system to compensate for plant uptake. Vertical bars indicate \pm SEM. Values of the same curve marked with different letters are significantly different at $P \leq 0.05$. 
All data were subjected to single-factor two-way analysis of variance. When a significant $\mathrm{F}$ test was obtained, all possible comparisons between the four treatment means were carried out by using Duncan's multiple range test $(P=0.05)$. The PlotIT3.2 ${ }^{\circledR}$ work package was used for both statistical analysis and plotting graphs.

\section{Results}

Plant growth. The supply of $10 \%\left(N_{r}=\right.$ $0.1)$ or $20 \%\left(N_{r}=0.2\right)$ of total $\mathrm{N}$ in the form of ammonium to lettuce plants grown in a completely closed hydroponic system had no effect on the fresh and dry weight of the plant shoot at the stage of commercial maturity in comparison with nitrate alone (Fig. 1). However, the further increase of $N_{r}$ to 0.3 significantly increased both the fresh and dry shoot weight of lettuce in the early spring experiment, whereas in the late spring only the fresh weight was significantly enhanced. The increase of the $\mathrm{NH}_{4}-\mathrm{N}$-to-total-N supply ratio to 0.3 also enhanced root fresh weight in the early spring experiment compared with the supply of $0,0.1$, and 0.2 of total $\mathrm{N}$ in the form of $\mathrm{NH}_{4}^{+}$, although root dry weight was not recorded in that experiment. In the late spring experiment, the results regarding the root fresh weight were not confirmed, whereas the highest root dry weight was measured when $N_{r}$ was 0.2 .

Nutrient solutions. The concentration of ammonium in the drainage solution, which indicates the $\mathrm{NH}_{4}^{+}$level in the root zone, ranged from 0 to $1.1 \mathrm{~mm}$ on day 15 after planting in the early spring experiment, in proportion to the ratios at which it was supplied (Fig. 2). However, on day 23 after planting and subsequently, the $\mathrm{NH}_{4}^{+}$concentrations in the drainage solution dropped to nearly zero in all treatments involving the delivery of a part of the total-N in the form of

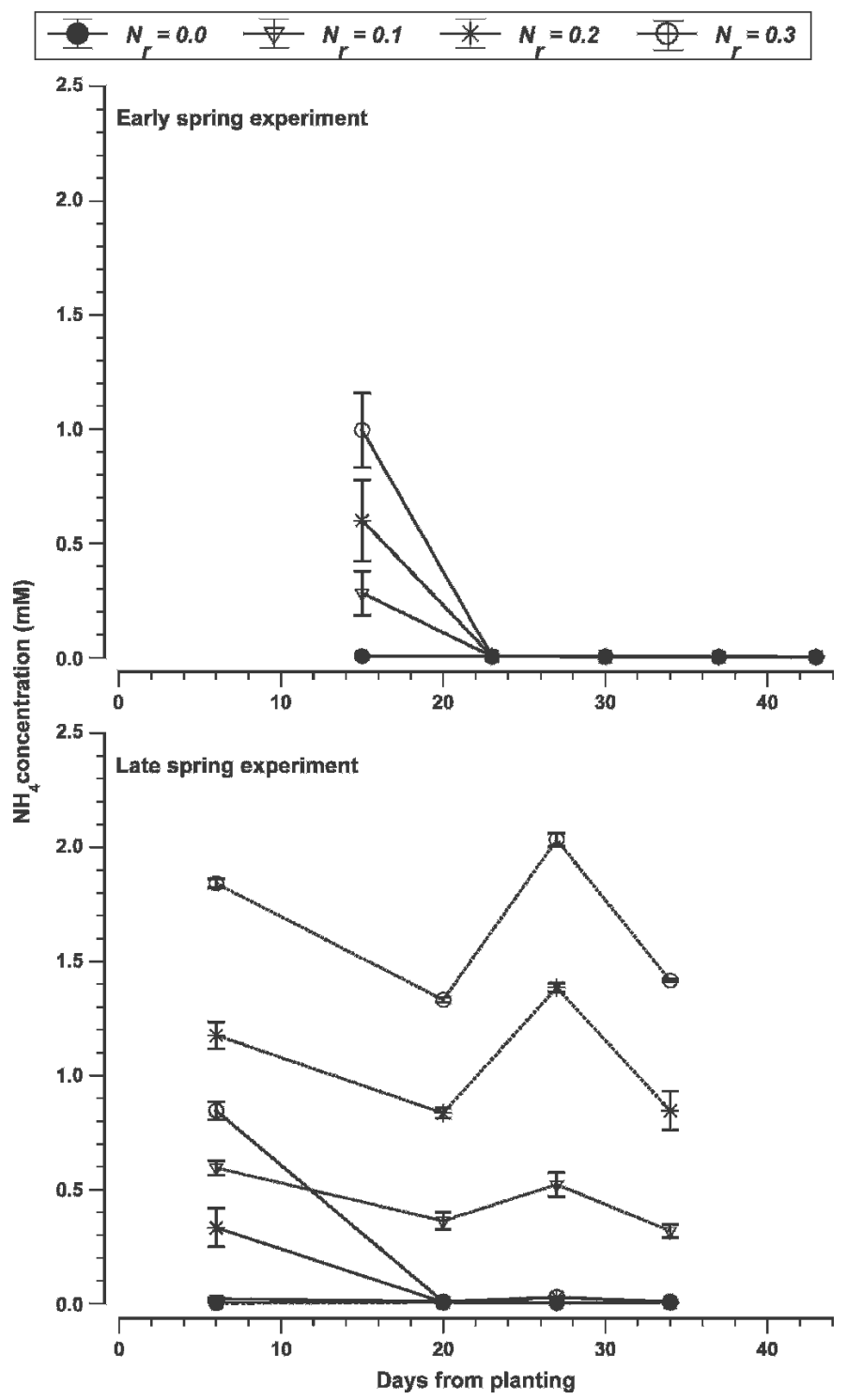

Fig. 2. Influence of $\mathrm{NH}_{4} /$ total- $\mathrm{N}\left(N_{r}\right)$ in the fresh nutrient solution introduced into a closed hydroponic system to compensate for nutrient and water uptake by lettuce on the $\mathrm{NH}_{4}$ concentration 1) in drainage solution (solid lines) and 2) in irrigation solution supplied to the crop (dotted line). Vertical bars indicate \pm SEM.

$\mathrm{NH}_{4}{ }^{+}$, irrespective of the level of $N_{r}$. Depletion of $\mathrm{NH}_{4}{ }^{+}$in the root zone of lettuce, as indicated by the concentrations measured in the drainage solution, was also observed in the late spring experiment, despite a constant $\mathrm{NH}_{4}{ }^{+}$delivery to the plants via the irrigation solution in three of the four treatments, which was proportional to $N_{r}$. The concentration of $\mathrm{NO}_{3}{ }^{-}$in the drainage solution was consistently reduced in both growing seasons as $N_{r}$ increased (Fig. 3). The concentrations of metallic nutrients and $\mathrm{P}$ in the drainage solution did not differ significantly between the treatments (data not shown).

The $\mathrm{pH}$ in the drainage solution decreased in both experiments as $N_{r}$ increased (Fig. 4). However, the $\mathrm{pH}$ rose above 6.5 on day 14 (early spring crop) and day 8 (late spring crop) after planting even at the two higher $N_{r}$ treatments and remained above that level throughout the cultivation. The average $\mathrm{pH}$ values calculated from the entire growth period were significantly lower as $N_{r}$ increased, with a consistent mean separation between the four treatments in the early spring experiment and a separation of the two lower $N_{r}$ levels from the two upper ones in the late spring experiment (Fig. 4).

Plant tissue. In both experiments, the increased supply of ammonium had no effect on the concentrations of macronutrient cations in the leaves of lettuce (Fig. 5). However, the leaf P concentration was enhanced as $N_{r}$ rose to levels above 0 and 0.1 in the early and the late spring experiment respectively. With respect to the micronutrient cations, the increase of $\mathrm{NH}_{4}{ }^{+}$supply did not affect the leaf $\mathrm{Fe}$ concentration in either of the two experiments or the leaf $\mathrm{Cu}$ content in the early spring crop, but the levels of $\mathrm{Zn}$ and $\mathrm{Mn}$ in the leaves were enhanced in both experiments by the increase in $N_{r}$ (Fig. 6). In particular, the leaf $\mathrm{Cu}$ concentration in the late spring experiment was enhanced by the supply of $10 \%$ of $\mathrm{N}$ in the form of $\mathrm{NH}_{4}^{+}\left(N_{r}=0.1\right)$ in comparison with $\mathrm{NO}_{3}{ }^{-}$as the sole $\mathrm{N}$ supply, but the further increase of $N_{r}$ to 0.2 and 0.3 did not additionally raise the leaf $\mathrm{Cu}$ level. The leaf $\mathrm{Zn}$ content was elevated in both experiments as $N_{r}$ rose from 0 to 0.1 , but to increase the leaf $\mathrm{Zn}$ concentration further, an $N_{r}$ level of 0.3 was required in the early spring crop, whereas in late spring no additional increase of $\mathrm{Zn}$ was observed as $N_{r}$ rose to 0.2 or 0.3 . In both experiments, the leaf $\mathrm{Mn}$ concentration was not influenced by the increase of $N_{r}$ from 0 to 0.2 , but the further elevation of $N_{r}$ to 0.3 significantly enhanced the leaf Mn levels.

The increase of $\mathrm{NH}_{4}-\mathrm{N} /$ total- $\mathrm{N}$ from 0 to 0.3 in the FNS that was introduced into the closed system to replace the amounts of nutrients and water taken up by the plants reduced the concentration of nitrate in the inner young leaves of lettuce in the early spring, but not in the late spring (Table 1). However, increasing the $\mathrm{NH}_{4}{ }^{+}$supply to plants had no effect on the $\mathrm{NO}_{3}{ }^{-}$concentration of the outer leaves of lettuce in either experiment. The organically bound $\mathrm{N}$ in the leaves declined significantly in the early spring 


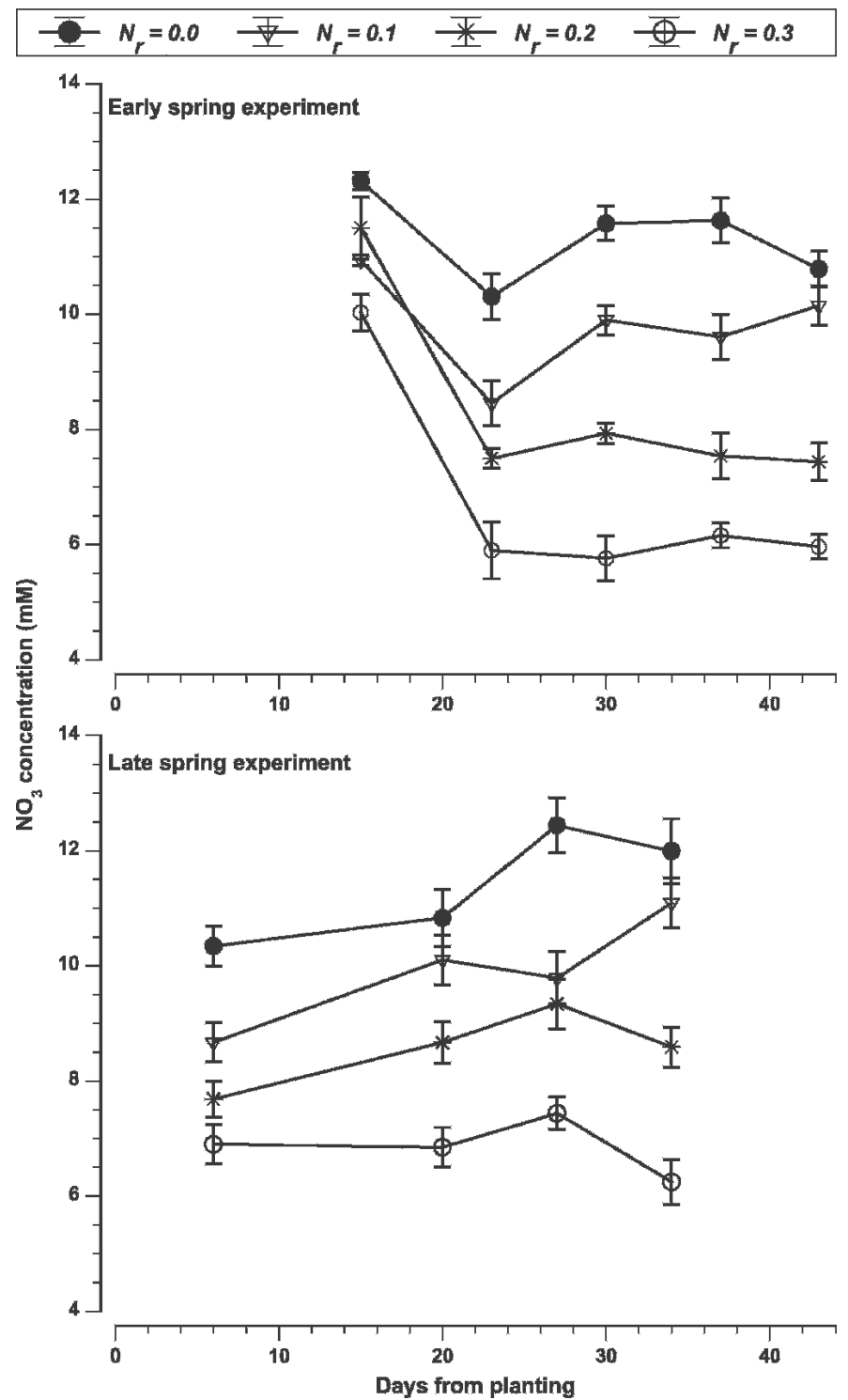

Fig. 3. Influence of $\mathrm{NH}_{4} /$ total-N $\left(N_{r}\right)$ in the fresh nutrient solution introduced into a closed hydroponic system to compensate for nutrient and water uptake by lettuce on the $\mathrm{NO}_{3}$ concentration in the drainage solution. Vertical bars indicate \pm SEM.

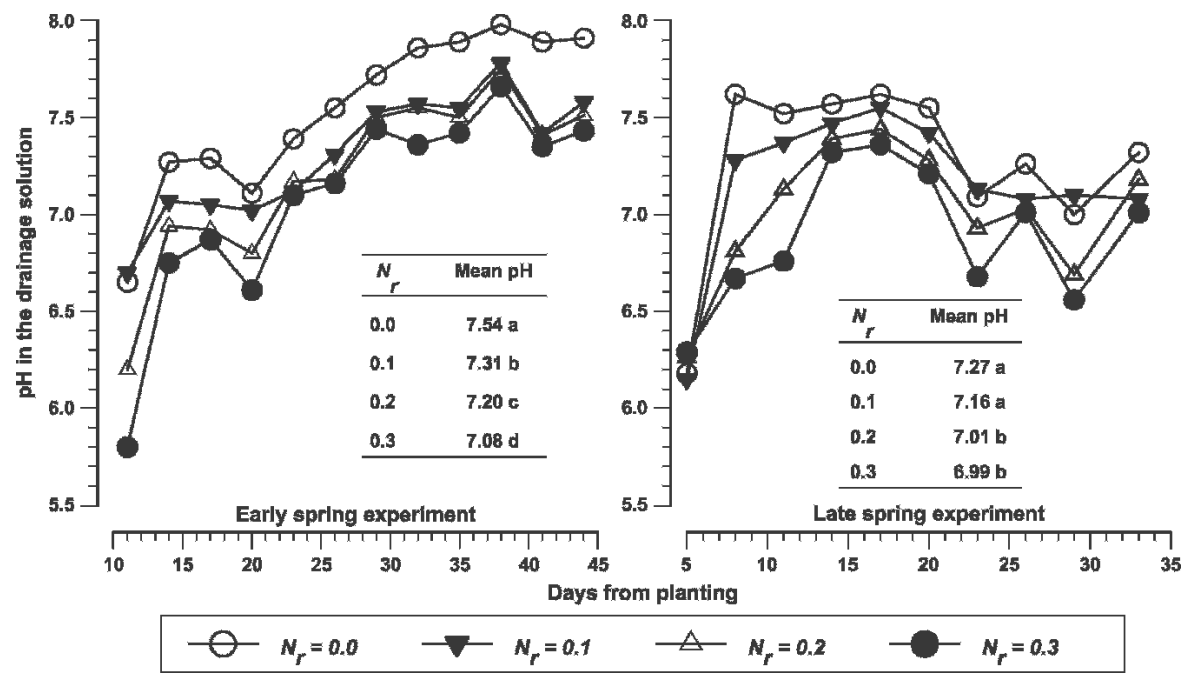

Fig. 4. Influence of $\mathrm{NH}_{4} /$ total-N $\left(N_{r}\right)$ in the fresh nutrient solution introduced into a closed hydroponic system to compensate for nutrient and water uptake by lettuce on drainage solution $\mathrm{pH}$. Points represent average values of 3-d intervals, whereas mean values correspond to the entire growing period. Different letters adjacent to mean $\mathrm{pH}$ values in each experiment indicate significant differences at $P \leq 0.05$. experiment as $N_{r}$ increased, but in the late spring experiment no significant differences between treatments could be established.

\section{Discussion}

Many investigators have reported a stimulatory effect of $\mathrm{NH}_{4}-\mathrm{N}$ on plant growth and development when ammonium is not the major source of N (Gerandás and Sattelmacher, 1990; Gerendás et al., 1997; Savvas et al., 2003; Sonneveld, 2002). However, most plants exhibit growth reduction and severe toxicity symptoms if ammonium is the dominant or sole form of supplied nitrogen (Gerendás et al., 1997; Guo et al., 2002; Raab and Terry, 1994). Even if ammonium is not the predominant source of $\mathrm{N}$, the growth of many plant species may be restricted when the $\mathrm{NH}_{4}$-N/total-N ratio $\left(N_{r}\right)$ exceeds a threshold (Bar-Tal et al., 2001; Sonneveld, 2002). Plant species vary in their response to a particular $N_{r}$ (Beevers and Hageman, 1983; Claussen and Lenz, 1999; Stensvand and Gislerød, 1992). Furthermore, this response relates to the rooting medium (Magalhaes and Wilcox, 1984), the root temperature (Frota and Tucker, 1972; Ganmore-Neumann and Kafkafi, 1980), and the root zone $\mathrm{pH}$ (Claussen and Lenz, 1999; Marschner, 1995).

The rooting medium (soil, soilless substrate, pure nutrient solution) influences the response of plants to the $\mathrm{NH}_{4}-\mathrm{N} /$ total-N supply ratio due mainly to its chemical properties, specifically the cation exchange capacity, which may alter $\mathrm{NH}_{4}{ }^{+}$availability in the root zone (Magalhaes and Wilcox, 1984) and the rhizosphere $\mathrm{pH}$ (Chaignon et al., 2002). However, in our experiments, the growth medium was the same in all treatments. High temperatures in the root zone are generally associated with a higher susceptibility of plants to increasing $\mathrm{NH}_{4}^{+}$supply, presumably because of enhanced consumption of carbohydrates by root respiration, which may decrease the availability of carbon skeletons for ammonia detoxification (Gerendás et al., 1997; Kafkafi, 1990). The root temperature was similar in all the treatments of each experiment in the current study, but was generally higher in late spring than in early spring. The different temperature conditions between the two trials may account for the weaker responses of lettuce to $\mathrm{NH}_{4}{ }^{+}$in the late spring experiment in comparison with those observed in early spring. With respect to the impact of the root zone $\mathrm{pH}$ on $\mathrm{NH}_{4}-\mathrm{N}$ nutrition, a level of about 6 seems to be optimal for growth in ammonium-fed plants (Wiesler, 1997). Lower $\mathrm{pH}$ levels restrict the conversion of $\mathrm{NH}_{4}^{+}$to organic $\mathrm{N}$ compounds in the root, thereby increasing the transport of free ammonium to the shoot with detrimental consequences for plant metabolism (Barker et al., 1966). An alkaline root zone $\mathrm{pH}$ is also harmful to $\mathrm{NH}_{4}{ }^{+}$-fed plants because of the enhanced conversion of $\mathrm{NH}_{4}{ }^{+}$to free ammonia, which is highly toxic to root cells (Marschner, 1995).

Although the impact of $\mathrm{NH}_{4}{ }^{+}$on plant growth depends strongly on the root zone 


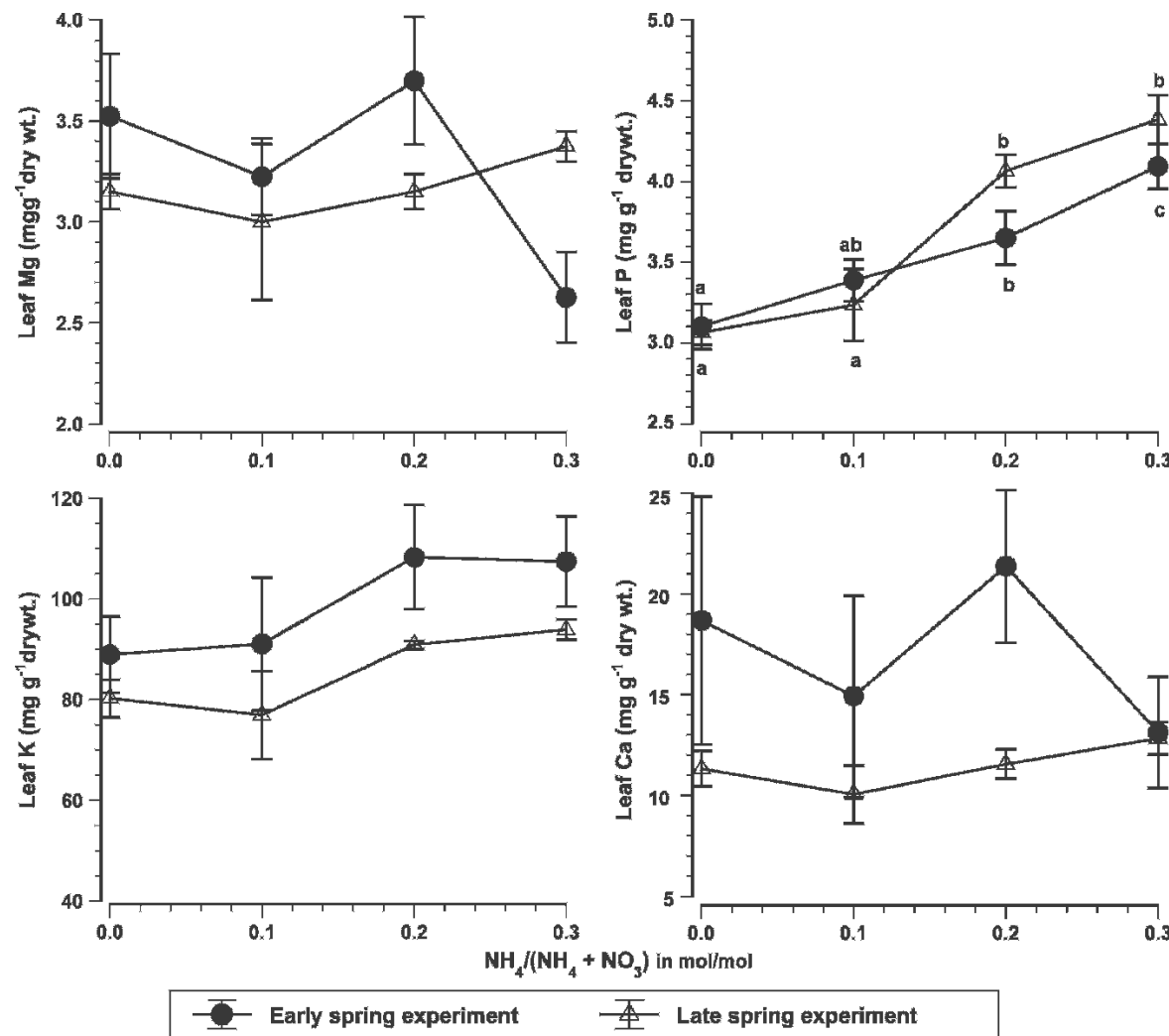

Fig. 5. Concentrations of $\mathrm{K}, \mathrm{Ca}, \mathrm{Mg}$, and $\mathrm{P}$ in the leaves of lettuce as influenced by $\mathrm{NH}_{4} /$ total-N $\left(N_{r}\right)$ in the fresh nutrient solution introduced into a closed hydroponic system to compensate for nutrient and water uptake by the plants. Vertical bars indicate \pm SEM. Values of the same curve marked with different letters are significantly different at $P \leq 0.05$.
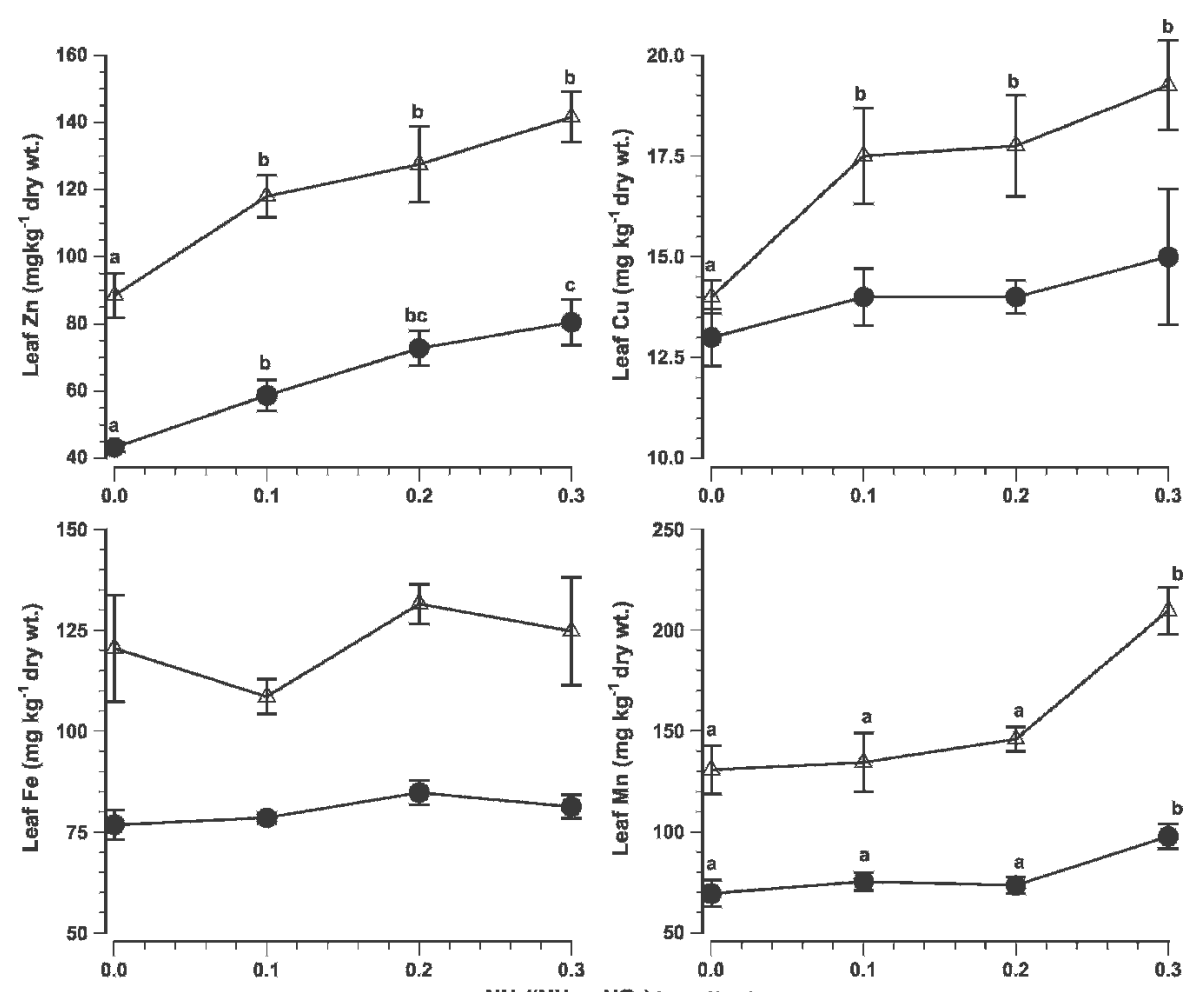

$\mathrm{NH}_{4} / \mathrm{NH}_{4}$

Early spring experiment

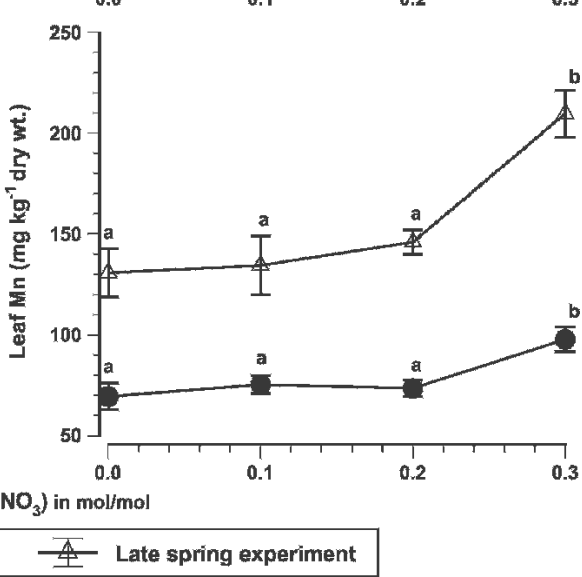

Fig. 6. Concentrations of micronutrient cations in the leaves of lettuce as influenced by $\mathrm{NH}_{4} / \operatorname{total}-\mathrm{N}\left(N_{r}\right)$ in the fresh nutrient solution introduced into a closed hydroponic system to compensate for nutrient and water uptake by the plants. Vertical bars indicate \pm sEM. Values of the same curve marked with different letters are significantly different at $P \leq 0.05$.
$\mathrm{pH}$, the latter is also influenced by the $\mathrm{NH}_{4}$ $\mathrm{N} /$ total-N supply ratio as outlined earlier. Hence, in some experiments, to exclude secondary $\mathrm{NH}_{4}{ }^{+}$effects on the plants because of their impact on the root zone $\mathrm{pH}$, the latter was consistently adjusted to the same level in all treatments (e.g., Claussen and Lenz, 1999; Guo et al., 2002). Because our experiments were aimed at investigating the impact of the $\mathrm{NH}_{4}$ supply in closed hydroponic systems under commercial growing conditions, the $\mathrm{pH}$ was adjusted only in the irrigation solution delivered to the plants. As a result, differences in the anion-to-cation uptake ratio brought about by the level of supplied $\mathrm{NH}_{4}$ caused differences in the root zone $\mathrm{pH}$. Hence, growth enhancement at the highest $N_{r}$ level was probably the result of a more favorable root zone $\mathrm{pH}$. Possible mechanisms underlying $\mathrm{pH}$-related growth improvement are discussed later. Nevertheless, even the inclusion of $30 \%$ of total-N in the form of $\mathrm{NH}_{4}{ }^{+}$was not sufficient to decrease the $\mathrm{pH}$ in the root zone of lettuce to levels between 5 and 6 , which are considered optimal for most hydroponically grown plants (Adams, 2002; Sonneveld, 2002). The establishment of relatively high $\mathrm{pH}$ levels in all treatments and in both experiments was obviously a result of $\mathrm{NH}_{4}{ }^{+}$depletion in the root zone.

According to Sonneveld (2002), the supply of $10 \%$ to $15 \%$ of total-N in the form of $\mathrm{NH}_{4}{ }^{+}$is optimal for most crops grown hydroponically on inert substrates, whereas an $N_{r}$ higher than 0.15 to 0.20 is associated with an increased risk of ammonium toxicity. In our experiments, even the supply of $30 \%$ of total-N in the form of $\mathrm{NH}_{4}{ }^{+}$was not harmful, but rather beneficial, to lettuce. However, in both trials, the ammonium concentration in the root zone was extremely low after the initial 2 to 3 weeks of growth, despite the much higher concentrations in the irrigation solution. Conversion of ammonium to ammonia is negligible at $\mathrm{pH}$ values $<7.5$ (De Rijck and Schrevens, 1997), and thus depletion of $\mathrm{NH}_{4}{ }^{+}$resulting from gaseous losses of ammonia is not likely. Indeed, depletion of $\mathrm{NH}_{4}{ }^{+}$in the drainage solution occurred even when $N_{r}$ was 0.3 , although the $\mathrm{pH}$ in the root zone was consistently less than 7.5, particularly in the late spring experiment. Nitrification of $\mathrm{NH}_{4}^{+}$may have occurred to some extent, but this was presumably not the main reason for the depletion of ammonium from the root zone. Indeed, the $\mathrm{NO}_{3}{ }^{-}$concentration in the drainage solution decreased with increasing $\mathrm{NH}_{4}^{+}$supply (Fig. 3), obviously reflecting the reduced $\mathrm{NO}_{3}{ }^{-}$levels in the FNS, which were necessary to maintain the same total-N concentration in all treatments. However, a complete microbial conversion of $\mathrm{NH}_{4}{ }^{+}$into $\mathrm{NO}_{3}{ }^{-}$would have resulted in similar nitrate concentrations in the drainage solution of all treatments, given that the total$\mathrm{N}$ supply was identical in all treatments and the nitrogen concentrations in the plant tissues were similar or even lower at high $N_{r}$. Depletion of $\mathrm{NH}_{4}{ }^{+}$in the drainage solution resulting from adsorption by pumice is also unlikely, because this substrate has a very 
Table 1. Concentrations of nitrate and organically bound $\mathrm{N}$ in the leaves of lettuce grown in a closed hydroponic system as influenced by $\mathrm{NH}_{4} /$ total- $\mathrm{N}$ in the fresh nutrient solution introduced into the system to compensate for nutrient and water uptake by the plants. ${ }^{z}$

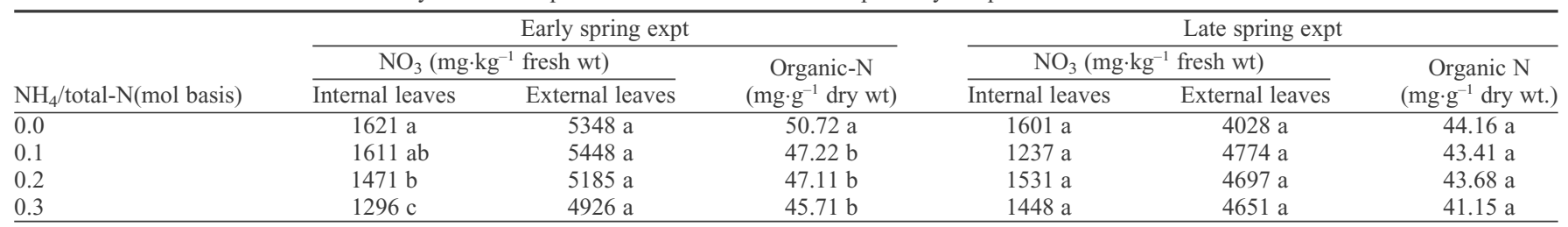

${ }^{2}$ Values are means of four measurements. Mean separation in columns is by Duncan's multiple range test. In each column, values followed by the same letter do not differ significantly at $P \leq 0.05$.

low cation exchange capacity (Gizas et al., 1999; Raviv et al., 2002). Thus, it seems that lettuce belongs to that group of species that is capable of absorbing $\mathrm{NH}_{4}^{+}$more rapidly than $\mathrm{NO}_{3}{ }^{-}$from a mixed $\mathrm{NO}_{3}{ }^{-} / \mathrm{NH}_{4}{ }^{+}$source (Forde and Clarkson, 1999). Depletion of $\mathrm{NH}_{4}{ }^{+}$in the drainage solution was also observed in gerbera grown in a closed hydroponic system (Savvas and Gizas, 2002). When a plant species with a preference for $\mathrm{NH}_{4}{ }^{+}$absorption is grown in closed hydroponic systems, $N_{r}$ should be increased to higher levels than those suggested for systems with free drainage to prevent $\mathrm{NH}_{4}{ }^{+}$depletion in the root zone, which might result in excessively high $\mathrm{pH}$ levels in the rhizosphere.

Many investigators concerned with the effects of $\mathrm{NH}_{4}^{+}$on plants have reported reduced uptake of major cations $(\mathrm{K}, \mathrm{Ca}$, $\mathrm{Mg}$ ) with increasing external $\mathrm{NH}_{4}{ }^{+}$concentrations (e.g., Chance et al., 1999; Pill and Lambeth, 1977; Wiesler, 1997). However, under the conditions of our experiment, soon after initiation of drainage solution recycling there was hardly any $\mathrm{NH}_{4}^{+}$in the root zone to influence the uptake of $\mathrm{K}, \mathrm{Ca}$, or $\mathrm{Mg}$ antagonistically. As a consequence, the concentrations of the latter in the leaves of lettuce were not significantly reduced by the enhanced ammonium supply. In contrast, the concentrations of $\mathrm{P}, \mathrm{Mn}$, and $\mathrm{Zn}$ in the leaves of lettuce increased as $N_{r}$ rose. It is wellknown that these nutrients become less soluble as the $\mathrm{pH}$ increases, which is particularly marked as $\mathrm{pH}$ increases to levels more than 6.0 (Adams, 2002; Marschner, 1995). Hence, the effect of the increased $\mathrm{NH}_{4}{ }^{+}$supply on $\mathrm{P}$, $\mathrm{Mn}$, and $\mathrm{Zn}$, as well as on $\mathrm{Cu}$ in the late spring experiment may be ascribed to the impact of $\mathrm{NH}_{4}{ }^{+}$on the rhizosphere $\mathrm{pH}$. Despite the high rhizosphere $\mathrm{pH}$, the leaf concentrations of $\mathrm{Mn}, \mathrm{Zn}$, and $\mathrm{Cu}$ were in all treatments far above the critical levels for deficiency (Marschner, 1995, Mills and Jones, 1996), which rules out growth stimulation at the highest $N_{r}$ level resulting from a more abundant supply of micronutrients. However, when $N_{r}$ was 0 or 0.1 , the leaf P concentration was only slightly above $3 \mathrm{mg} \cdot \mathrm{g}^{-1}$ dry weight, which is considered to be the critical level for $\mathrm{P}$ deficiency (Marschner, 1995), whereas in the treatment with the highest $\mathrm{NH}_{4}-\mathrm{N} /$ total-N supply ratio the leaf $\mathrm{P}$ was significantly higher $\left(4.1 \mathrm{mg} \cdot \mathrm{g}^{-1}\right.$ and $4.4 \mathrm{mg} \cdot \mathrm{g}^{-1}$ dry weight in the early and late spring trials respectively). Hence, the stimulatory effect of $\mathrm{NH}_{4}{ }^{+}$on lettuce growth was presumably associated with a more efficient $\mathrm{P}$ supply, resulting from a more favorable $\mathrm{pH}$ in the root zone, although energy savings (Raab and Terry, 1994) and alterations in the phytohormone balance (Smiciklas and Below, 1992; Wiesler, 1997) may have also been involved. On the other hand, because the increase of $N_{r}$ by maintaining the same total-N level did not enhance the concentration of organic $\mathrm{N}$ in the shoot of lettuce, the stimulation of growth at the highest $N_{r}$ level was not the result of improved $\mathrm{N}$ nutrition.

Restriction of leaf $\mathrm{NO}_{3}{ }^{-}$in lettuce with increasing $\mathrm{NH}_{4}-\mathrm{N}$ /total-N has also been observed by Van der Boon et al. (1990). Gent (2003) reported increased $\mathrm{NO}_{3}{ }^{-}$levels in the leaves of lettuce grown in a closed hydroponic system as the external $\mathrm{NO}_{3}{ }^{-}$concentration was elevated. However, in our study, a reduction of $\mathrm{NO}_{3}{ }^{-}$concentration as $N_{r}$ increased was observed only in the inner (younger) leaves and only in the early spring. Given that nitrate is transported via the transpiration stream to the leaves and accumulates in the vacuoles (Pate, 1980), it seems that the storage capacity of the latter in the old leaves was saturated as a result of prolonged transpiration, thereby minimizing the impact of different external $\mathrm{NO}_{3}{ }^{-}$concentrations on $\mathrm{NO}_{3}{ }^{-}$deposition. The different response of lettuce to $N_{r}$ with respect to $\mathrm{NO}_{3}$ accumulation in the leaves observed in the early and late spring experiments seems to originate from seasonal differences, particularly solar radiation, which has a strong impact on the nitrate reductase activity (Marschner, 1995), and temperature, which accelerates both nitrification and plant metabolism. Van der Boon et al. (1990) also found a more profound effect of $N_{r}$ on the leaf $\mathrm{NO}_{3}{ }^{-}$concentration of lettuce in the winter than in the summer.

In conclusion, lettuce is not susceptible to micronutrient deficiencies if $\mathrm{NO}_{3}-\mathrm{N}$ is the only $\mathrm{N}$ source in hydroponically grown crops, although under such conditions the $\mathrm{pH}$ in the root zone may reach levels more than 7. Lettuce preferentially takes up $\mathrm{NH}_{4}-\mathrm{N}$ over $\mathrm{NO}_{3}-\mathrm{N}$, and this may lower the nitrate concentrations in the internal leaves, depending on the growth season. However, the rapid uptake of $\mathrm{NH}_{4}-\mathrm{N}$ by lettuce does not enhance the level of organically bound $\mathrm{N}$ in the shoot when the $\mathrm{NH}_{4}-\mathrm{N} /$ total-N supply ratio increases but the total-N supply remains constant. The supply of at least $30 \%$ of total-N in the form of $\mathrm{NH}_{4} \mathrm{SO}_{4}$ by maintaining the concentrations of total $\mathrm{N}$ and all other nutrients except $\mathrm{SO}_{4}{ }^{2-}$ at the standard suggested levels seems to stimulate lettuce growth in pumice when the drainage solution is recycled. The stimulation of lettuce growth by $\mathrm{NH}_{4}{ }^{+}$may be associated with enhanced phosphorus uptake resulting from better control of $\mathrm{pH}$ in the root zone.

\section{Literature Cited}

Adams, P. 2002. Nutritional control in hydroponics, p. 211-261. In: D. Savvas and H.C. Passam (eds.). Hydroponic production of vegetables and ornamentals. Embryo Publishers, Athens, Greece.

Akl, I.A., D. Savvas, N. Papadantonakis, N. LydakisSimantiris, and P. Kefalas. 2003. Influence of ammonium to total nitrogen supply ratio on growth, yield and fruit quality of tomato grown in a closed hydroponic system. Eur. J. Hort. Sci. 68:204-211.

Barber, S.A. 1984. Nitrogen, p. 179-197. In: S.A. Barber (ed.). Soil nutrient availability: A mechanistic approach. Wiley-Interscience, New York.

Barker, A.V. and H.A. Mills. 1980. Ammonium and nitrate nutrition of horticultural crops. Hort. Rev. (Amer. Soc. Hort. Sci.) 2:395-423.

Barker, A.V., R.J. Volk, and W.A. Jackson. 1966. Root environment acidity as a regulatory factor in ammonium assimilation by the bean plant. Plant Physiol. 41:1193-1199.

Bar-Tal, A., B. Aloni, L. Karni, and R. Rosenberg. 2001. Nitrogen nutrition of greenhouse pepper. II. Effects of nitrogen concentration and $\mathrm{NO}_{3}: \mathrm{NH}_{4}$ ratio on growth, transpiration, and nutrient uptake. HortScience 36:1252-1259.

Beevers, L. and R.H. Hageman. 1983. Uptake and reduction of nitrate: Bacteria and higher plants, p. 351-375. In: A. Läuchli and R.L. Bieleski (eds.). Encyclopedia of plant physiology, new series. Vol. 15A. Springer Verlag, Berlin.

Blom-Zandstra, M. 1989. Nitrate accumulation in vegetables and its relationship to quality. Ann. Appl. Biol. 115:553-561.

Bolan, N.S., M.J. Hedley, and R.E. White. 1991. Processes of soil acidification during nitrogen cycling with emphasis on legume based pastures, p. 169-179. In: R.J. Wright, V.C. Baligar, and R.P. Murrmann (eds.). Plant-soil interactions at low $\mathrm{pH}$. Kluwer Academic Publishers, Dordrecht, the Netherlands.

Cataldo, D.A., M. Haroon, L.E. Schrader, and V.L. Youngs. 1975. Rapid colorimetric determination of nitrate in plant tissue by nitration of salicylic acid. Commun. Soil Sci. Plant Anal. 6:71-80.

Chaignon, V., F. Bedin, and P. Hinsinger. 2002. Copper bioavailability and rhizosphere $\mathrm{pH}$ changes as affected by nitrogen supply for tomato and oilseed rape cropped on an acidic and a calcareous soil. Plant Soil 243:219-228.

Chaillou, S., J.F. Morot-Gaudry, C. Lesaint, L. Salsac, and E. Joliver. 1986. Nitrate or ammonium nutrition in French bean. Plant Soil 91: 363-365. 
Chance, W.O., Z.C. Somda, and H.A. Mills. 1999. Effect of nitrogen form during the flowering period on zucchini squash growth and nutrient element uptake. J. Plant Nutr. 22:597-607.

Claussen, W. and F. Lenz. 1999. Effect of ammonium or nitrate nutrition on net photosynthesis, growth, and activity of the enzymes nitrate reductase and glutamine synthetase in blueberry, raspberry and strawberry. Plant Soil 208:95-102.

De Rijck, G. and E. Schrevens. 1997. Elemental bioavailability in nutrient solutions in relation to dissociation reactions. J. Plant Nutr. 20:901-910.

Eaton, A.D., L.S. Clesceri, and A.E. Greenberg (eds.). 1995. Standard methods for the examination of water and wastewater. 19th ed. Amer. Public Health Assn. Washington, DC.

Forde, B.G. and D.T. Clarkson. 1999. Nitrate and ammonium nutrition of plants: Physiological and molecular perspectives. Adv. Bot. Res. 30:1-90

Frota, J.N.E. and T.C. Tucker. 1972. Temperature influence on ammonium and nitrate absorption by lettuce. Soil Sci. Soc. Amer. Proc. 36:97-100.

Ganmore-Neumann, R. and U. Kafkafi. 1980. Root temperature and percentage $\mathrm{NO}_{3}-\mathrm{NH}_{4}+$ effect on tomato plant development. I. Morphology and growth. Agron. J. 72:758-761.

Gent, M. 2003. Solution electrical conductivity and ratio of nitrate to other nutrients affect accumulation of nitrate in hydroponic lettuce. HortScience 38:222-227.

Gerandás, J. and B. Sattelmacher. 1990. Influence of nitrogen form and concentration on growth and ionic balance of tomato (Lycopersicum esculentum) and potato (Solanum tuberosum), p. 33-37. In: M.L. van Beusichem (ed.). Plant nutrition: Physiology and applications. Kluwer Academic Publishers, Dordrecht, the Netherlands.

Gerendás, J., Z. Zhu, R. Bendixen, R.G. Ratcliffe, and B. Sattelmacher. 1997. Physiological and biochemical processes related to ammonium toxicity in higher plants. Z. Pflanzenernähr. Bodenk. 160:239-251.

Givan, C.V. 1979. Metabolic detoxification of ammonia in tissues of higher plants. Phytochemistry 18:375-382.

Gizas, G., D. Savvas, and I. Mitsios. 1999. Availability of macrocations in perlite and pumice as influenced by the application of nutrient solutions having different cation concentration ratios. Acta Hort. 548:277-284.

Guo, S., H. Brück, and B. Sattelmacher. 2002. Effects of supplied nitrogen form on growth and water uptake of French bean (Phaseolus vulgaris L.) plants. Plant Soil 239:267-275.

Ikeda, H. and T. Osawa. 1981. Nitrate and ammonium-N absorption by vegetables from nutrient solution containing ammonium nitrate and the resultant change of solution $\mathrm{pH}$. J. Jpn. Soc. Hort. Sci. 50:225-230.

Imas, P., B. Bar-Yosef, U. Kafkafi, and R. Ganmore-Neumann. 1997. Release of carboxylic anions and protons by tomato roots in response to ammonium nitrate ratio and $\mathrm{pH}$ in nutrient solution. Plant Soil 191:27-34.

Islam, A.K.M.S., D.G. Edwards, and C.J. Asher. 1980. pH optima for crop growth. Results of a flowing solution culture experiment with six species. Plant Soil 54:339-357.

Kafkafi, U. 1990. Root temperature, concentration and ratio $\mathrm{NO}_{3}-\mathrm{NH}_{4}+$ effect on plant development. J. Plant Nutr. 13:1291-1306.

Lea-Cox, J.D., G.W. Stutte, W.L. Berry, and R.M. Wheeler. 1996. Charge balance: A theoretical basis for modulating $\mathrm{pH}$ fluctuations in plant nutrient delivery systems. Life Support Biosph. Sci. 3:53-59.

Magalhaes, J.R. and G.E. Wilcox. 1983. Tomato growth and mineral composition as influenced by nitrogen form and light intensity. J. Plant Nutr. 6:847-862.

Magalhaes, J.R. and G.E. Wilcox. 1984. Growth, free amino acids, and mineral composition of tomato plants in relation to nitrogen form and growing media. J. Amer. Soc. Hort. Sci. 109:406-411.

Marschner, H. 1995. Mineral nutrition of higher plants. 2nd ed. Academic Press, London.

Mills, H.A. and J. Jones Jr. 1996. Plant analysis handbook II. MicroMacro Publishing. Athens, Ga.

Pate, J.S. 1980. Transport and partitioning of nitrogenous solutes. Annu. Rev. Plant Physiol. 31:313-340

Pill, W.G. and V.N. Lambeth. 1977. Effects of $\mathrm{NH}_{4}$ and $\mathrm{NO}_{3}$ nutrition with and without $\mathrm{pH}$ adjustment on tomato growth, ion composition and water relations. J. Amer. Soc. Hort. Sci. 102:78-81.
Raab, T.K. and N. Terry. 1994. Nitrogen-source regulation of growth and photosynthesis in Beta vulgaris L. Plant Physiol. 105:1159-1166.

Raviv, M., R. Wallach, A. Silber, and A. Bar-Tal. 2002. Substrates and their analysis, p. 25-101. In: D. Savvas, and H.C. Passam (eds.). Hydroponic production of vegetables and ornamentals. Embryo Publishers, Athens, Greece.

Savvas, D. and G. Gizas. 2002. Response of hydroponically grown gerbera to nutrient solution recycling and different nutrient cation ratios. Sci. Hort. (Amsterdam) 96:267-280.

Savvas, D., V. Karagianni, A. Kotsiras, V. Demopoulos, I. Karkamisi, and P. Pakou. 2003. Interactions between ammonium and $\mathrm{pH}$ of the nutrient solution supplied to gerbera (Gerbera jamesonii) grown in soilless culture. Plant Soil 254:393-402.

Scaife, A., M.E.S. Ferreira, and M.K. Turner. 1986. Effect of nitrogen form on the growth and nitrate concentration of lettuce. Plant Soil 94: 3-16.

Shannon, M.C. and C.M. Grieve. 1999. Tolerance of vegetable crops to salinity. Sci. Hort. (Amsterdam) 78:5-38.

Smiciklas, K.D. and F.E. Below. 1992. Role of cytokinine in enhanced productivity of maize supplied with $\mathrm{NH}_{4}+$ and $\mathrm{NO}_{3}-$. Plant Soil 142:307-313.

Sonneveld, C. 2002. Composition of nutrient solutions, p. 179-210. In: D. Savvas, and H.C. Passam (eds.). Hydroponic production of vegetables and ornamentals. Embryo Publishers, Athens, Greece.

Stensvand, A. and H.R. Gislerød. 1992. The effect of the $\mathrm{NO}_{3} / \mathrm{NH}_{4}$ ratio of the nutrient solution on growth and mineral uptake in Chrysanthemum xmorifolium, Passiflora caerulea, and Cordyline fruticosa. Gartenbauwissenschaft 57:193-198.

Van der Boon, J.W., J.W. Steenhuizen, and E.G. Steingröver. 1990. Growth and nitrate concentration of lettuce as affected by total nitrogen and chloride concentration, $\mathrm{NH}_{4} / \mathrm{NO}_{3}$ ratio and temperature of the recirculating nutrient solution. J. Hort. Sci. 65:309321.

Wiesler, F. 1997. Agronomical and physiological aspects of ammonium and nitrate nutrition of plants. Z. Pflanzenernähr. Bodenk. 160:227238. 